\title{
JUVENTUDES, COTIDIANO E UM "CADINHO" MAIS... ENTREVISTA COM ELIANE RIBEIRO'
}

\section{YOUTH, EVERYDAY AND A "CADINHO" MORE ... INTERVIEW WITH ELIANE RIBEIRO}

\author{
ARCURI, Christiane ${ }^{2}$ \\ SILVA, Lincoln Tavares ${ }^{3}$
}

\begin{abstract}
Filmagem: Alan Lopes ${ }^{4}$ e Milena Viegas Campos da Ressurreição ${ }^{5}$
Transcrição: Alan Lopes e Milena Viegas da Ressurreição

Revisão: Andrea da Paixão Fernandes ${ }^{6}$
\end{abstract}

A e-Mosaicos - Revista Multidisciplinar de Ensino, Pesquisa, Extensão e Cultura do Instituto de Aplicação Fernando Rodrigues da Silveira (CAp-UERJ) convida Eliane Ribeiro, Professora em Educação da Universidade Federal do Estado do Rio de Janeiro (UNIRIO) para uma entrevista sobre os temas juventude, escola e consumo. Com os projetos de pesquisa "Perfil, formação escolar e trajetória de jovens que não estudam e não trabalham no Brasil: desigualdades e possibilidades na perspectiva da coesão social" (2017) e "Juventude, escola e trabalho: um estudo sobre transição para vida adulta no Brasil e no estado do Rio de Janeiro" (2016), a professora Eliane Ribeiro participa dessa edição justamente devido ao seu trabalho no campo da Educação de Jovens e Adultos (EJA) e das juventudes, sobretudo no que se refere à formação escolar e às trajetórias dos jovens que estão fora da escola e do mundo do trabalho, considerando as desigualdades e possibilidades com as quais lidamos no contexto brasileiro.

\footnotetext{
${ }^{1}$ Professora da Universidade Federal do Estado do Rio de Janeiro (UNIRIO) - Escola de Educação; Faculdade de Ciências Sociais e Programa de Pós-graduação em Educação.http://buscatextual.cnpq.br/buscatextual/visualizacv.do?id=K4758973T1

2 Professora Adjunta da Universidade do Estado do Rio de Janeiro (UERJ) - Instituto de Aplicação / CAp. e-mail: arcuriarte@gmail.com

${ }^{3}$ Professor Adjunto da Universidade do Estado do Rio de Janeiro (UERJ), do Instituto de Aplicação Fernando Rodrigues da Silveira (CAp-UERJ) e do Programa de Pós-Graduação de Ensino em Educação Básica (PPGEB/CAp-UERJ). e-mail: lincolntsilva@hotmail.com

${ }^{4}$ Graduando em Pedagogia, da Faculdade de Educação da UERJ. Bolsista do Projeto de Extensão Universitária Dialogias em Humanidades (CEH/UERJ). e-mail: alfalopes@msn.com

${ }^{5}$ Graduanda em Letras do Instituto de Letras da UERJ. Bolsista do Projeto de Extensão Universitária e-Mosaicos - Revista Multidisciplinar de Ensino, Pesquisa, Extensão, Cultura do Instituto de Aplicação Fernando Rodrigues da Silveira (CAp-UERJ). e-mail: mi.viegas@outlook.com

${ }^{6}$ Professora Adjunta da Universidade do Estado do Rio de Janeiro (UERJ), do Instituto de Aplicação Fernando Rodrigues da Silveira (CAp-UERJ) e do Programa de Pós-Graduação de Ensino em Educação Básica (PPGEB/CAp-UERJ). e-mail: andreaf@uerj.br
} 
Entrevistadores: Nós elaboramos algumas questões, em dois momentos, que partem muito dessa perspectiva da relação da escola, com a EJA, com jovens e com as contradições sociais. Outra parte seria a abordagem sobre seu processo de pesquisa, com foco nas juventudes e nas situações dos "nem-nem". Gostaríamos de falar sobre a dimensão desse trabalho e tudo o que diz respeito à sua pesquisa e à experiência em sala de aula.

Mas seria importante, antes, uma apresentação da Profa Christiane Arcuri, haja vista que tem um projeto de pesquisa e extensão que trata da identidade visual na escola, por meio do qual relaciona os objetos estéticos, de arte, que os alunos usam na escola, ou seja, mochilas, tênis e capa de caderno para ligar ao consumo na juventude. Foi essa pesquisa, além da importância da temática juventudes, um dos motivos da escolha da temática dessa edição especial, buscando pensar esse sistema voltado à identidade, à juventude, à escola e ao consumo.

Eliane Ribeiro: Bacana.

Em sua pesquisa, a professora Christiane Arcuri parte dos objetos que os jovens escolhem, o que eles usam. Questiona se eles usam esses objetos (com essas estampas, por exemplo) porque são obrigados a usar, ou porque os pais, os responsáveis, compraram. E se eles quiseram comprar (ou não), o que isso tem a ver com eles; como eles conseguem se agrupar e ter uma identidade visual através desse consumo?

Entrevistadores: 0 projeto da Chris é para criar novas identidades, na verdade. Enfatizar a arte nacional, tentar valorizar e ter uma noção do que existe, para não dizer: nossa isso é novo, isso é diferente, porque desconhece o que existe e fica mais fácil dizer que é novidade, que é diferente, né?

Eliane Ribeiro: Você vai andando e vai descobrindo as pessoas, cada um, por exemplo, este campo da juventude foi se abrindo, se abrindo e tirando a juventude também da escola.

Entrevistadores: Bom, então, como a e-mosaicos é uma revista multidisciplinar, acaba ultrapassando todas as áreas de ensino da educação, interfaceando com as ações que os professores costumam desempenhar nas escolas, no seu cotidiano. Não só nas escolas de aplicação, mas também nas escolas das redes públicas e privadas. Nós temos recebido um aporte bastante interessante de pesquisadores, de professores, que já tiveram "um pé" lá na educação básica e que conseguiram manter essa interface da universidade com a educação básica, que está ainda se formando lá nas cadeiras das escolas públicas e escolas privadas. Mas o nosso foco tem sido este, de tentar sempre trazer pessoas que possam contribuir para a formação do professor e, principalmente, com preocupações contemporâneas, com situações de conflitos, com situações que de fato têm nos angustiado, para as quais as pessoas têm buscado encontrar algumas soluções. Nós sabemos que a escola 


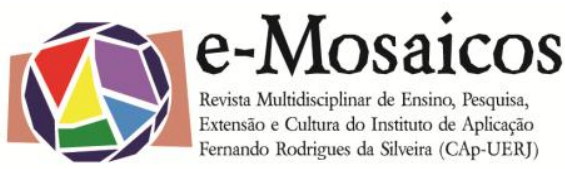

DOI: $10.12957 /$ e-mosaicos.2018.36937

exerce vários papéis, mas qual tem sido esse papel nas vidas dos jovens, principalmente dos jovens mais vulnerabilizados socialmente? 0 interesse é pelo papel dessa escola, principalmente da escola pública, qual deveria ser, ela não está conseguindo, ela consegue exercer o seu papel, principalmente em relação à vida desses mais vulnerabilizados?

Eliane Ribeiro: Eu acho que essa discussão parece simples, "o jovem não gosta de escola, a escola é ruim, ponto acabou, ponto final". Ela parece muito simples, mas ela é uma discussão extremamente complexa e a gente tem que ter muito cuidado para falar sobre juventude e escola porque eu acho que a tendência é a gente demonizar a escola - "escola não presta, a escola é ruim, a escola é isso, a escola é aquilo". Quando a gente estuda, quando a gente pesquisa, a gente percebe que é uma instituição que tem um papel para essa garotada super importante, entendeu? Eu acho que tem que separar primeiro o seguinte: a escola não somente como lugar que você vai para aprender coisas, as disciplinas; a escola é um espaço de sociabilidade fantástico, é um lugar no qual especialmente a juventude pobre faz redes. Porque as redes... quanto mais pobre, menos redes você tem. Assim, os poucos espaços que essa população tem são fundamentais. As pesquisas têm mostrado para a gente que a escola é um desses espaços. Tem um trabalho que a gente fez há muito tempo atrás com a Unesco que foi muito interessante: a gente pegou lideranças jovens, viu aonde que ele começa a se inserir, aonde era importante. Vimos que foi na escola, através da cultura, das artes - é na escola que um professor cria um grupo de teatro, que cria um grupo de dança, várias coisas bacanas.

Entrevistadores: A integração né?! Você chega na pesquisa pela EJA? Que relações você acha que podemos traçar entre os jovens brasileiros e a EJA nos tempos recentes?

Eliane Ribeiro: Por exemplo, já ouvi um colega falar assim: "poxa meu primo entrou para a universidade" - coisa que não estava nem na sua perspectiva. Daí ele começa: "como é que é isso? Isso é para gente?" Porque pra muita gente, a universidade não é um lugar para essa pessoa. Então, eu acho que a gente tem que ter cuidado com a forma como a gente trata e muitas vezes aborda a escola; acho que a escola tem um papel importante ainda na nossa sociedade e muitas vezes é o único equipamento social que esse jovem pobre tem. Helena Abramo fala uma coisa muito legal: "será que a escola cabe na vida desses jovens?" Como é que a gente pensa uma escola que cabe na vida do jovem, que possa potencializar esse jovem? Aí entra a questão do trabalho que é central e fundamental, especialmente na juventude a partir dos 16 anos, que tem que pensar, escola e trabalho. Não dá pra dizer... vai ficar estudando até os 26 anos. Isso não existe, na realidade e na prática, isso não existe. Então, como é que a gente pode ter conquistas nesse campo? Acho que a escola, muitas vezes, não cabe na vida desse jovem; acho que a gente tem muito estudo, muito trabalho que mostra para gente isso, por exemplo, uma jovem que engravida dentro da escola, o que é que acontece com essa jovem? É rapidamente convidada quase a sair... 
Entrevistadores: Sim, sim. Que retrato você faz das políticas públicas para a juventude? Onde elas têm deixado a desejar?

Eliane Ribeiro: Os processos de exclusão, por exemplo, um jovem que de alguma forma se envolve com a questão das drogas e tal, ele é convidado a sair. É quase como se a escola tivesse um padrão de aluno ideal que é aquele que tem que ficar ali numa escola que não existe, que não existe só com a classe média.

Entrevistadores: Sim.

Eliane Ribeiro: Entendeu? Então assim você fica trabalhando com a perspectiva de uma escola que não cabe na vida.

Entrevistadores: De um jovem perfeito ou de um jovem modelo para uma escola supostamente padrão.

Eliane: Exatamente. Você fica trabalhando em cima de modelos. Agora eu acho que isso não é uma coisa simples. Isso é culpa de quem? É culpa do Estado? É culpa dos professores? É uma questão. É uma transformação muito mais profunda e coletiva da nossa sociedade. O olhar a partir da educação de jovens e adultos ensina muito pra gente; a educação de jovens e adultos têm mostrado que os jovens e adultos voltam para escola a toda a hora. Ele está o tempo todo retornando. Jovens frutos não de uma escolaridade, mas frutos de uma universalização, com uma baixa qualidade, mas com possibilidades de futuro.

Entrevistadores: Com isso você está trazendo uma outra questão: as relações que a gente pode traçar entre os jovens brasileiros, embora isso seja também uma coisa generalizada. $E$ a EJA, nos tempos atuais, como é que essa ponte também tem se dado? Você também pesquisa esse assunto, pelo menos se debruçou durante um bom tempo nisso, o que você vê como perspectiva nesse cenário contraditório na sociedade brasileira? Antes de começarmos a entrevista, conversávamos sobre avanços e, agora, uma série de "retrocessos". Como é que a gente consegue encaixar jovens, EJA e essa perspectiva de cenário?

Eliane Ribeiro: Eu ouso dizer que nunca mais seremos os mesmos. Eu acho que essas conquistas têm impacto, entendeu?! Então, por mais que a gente tenha hoje um golpe, um governo horrível, que está tentando travar tudo, eu acho que de alguma forma, por outro lado, a gente tem uma juventude muito interessante, muito melhor que a nossa, do que a minha, do que a de vocês. Sinceramente, eu acho que muitas vezes as pessoas ficam nostálgicas: "Ah!, a juventude de 68" - imagina a juventude de 68... Eram meia dúzia jovens de classe média; eram muito bem posicionados. Hoje, você tem uma diversidade cultural, intelectual...

Entrevistadores: $\mathrm{O}$ acesso; a facilidade ao acesso é impressionante.

Eliane Ribeiro: Sobre a facilidade do acesso, eu acho que a gente tem, sem dúvida nenhuma, um grande caos, mas também a gente tem também um grande caldo, aí você pode estar falando assim: "Ih... a Eliane está muito otimista", tem que estar também, eu fiz 60 anos, se eu não tiver otimismo (risos) eu não sei para onde eu vou. 
DOI: $10.12957 /$ e-mosaicos.2018.36937

Lincoln: Você faz parte do mesmo clube do Milton Santos, por exemplo, ele dizia: "eu sou optimista".

Eliane Ribeiro: Exatamente (risos). Exatamente, eu acho que tem assim um caldo da juventude como nunca vimos - e olha que eu estou em sala de aula há 30 anos. Hoje é outra coisa, é muito mais interessante todas essas identidades que foram e que tiveram a possibilidade de aparecer. Então, a Educação de Jovens e Adultos, eu acho que ela hoje, quando a gente fala assim: "existe uma juvenilização da Educação de Jovens e Adultos", é mais ou menos, na verdade, dizer que os jovens sempre tiveram na Educação de Jovens e Adultos. O que a gente vê por diferença é que hoje é uma juventude que está vindo de uma universalização, né?! Que está nas políticas de correção de fluxo; que foram ficando ali nas evasões, nas repetências e tal. Eu entro na juventude pela Educação de Jovens e Adultos - a minha dissertação foi sobre isso, depois minha tese e doutorado também -, porque é com a Educação de Jovens e Adultos que eu começo a perceber que tem um monte de jovens ali, com um monte de histórias interessantíssimas e que eram invisibilizadas porque a imagem que se tinha da EJA era do velhinho com dificuldades de escrever e tal.

Entrevistadores: Sim, uma representação.

Eliane: Uma representação. Então, não era isso; era outra história. Eu acho que a gente tem um desafio hoje que é realmente um risco de não entender que, no Brasil, a EJA é uma modalidade essencial no sistema; isolar os jovens do sistema educacional, do ensino fundamental, do ensino médio não pode! A educação tem que ser pensada como um todo.

Entrevistadores: Nos sistemas.

Eliane Ribeiro: O aluno que vai para a Educação de Jovens e Adultos é aquele que: "Ah!, ele está dando problema; ah!, manda para a educação de jovens e adultos; ah!, ele tem deficiência, é para uma educação especial"; "ah!, manda para a educação de jovens e adultos".

Entrevistadores: Um jovem que acham que já passou da idade, do tempo sistêmico da escola.

Eliane Ribeiro: "Ah!, engravidou, manda para a Educação de Jovens e Adultos". Por outro lado, eu acho que a Educação de Jovens e Adultos humaniza muito a gente, nós todos, professores especialmente, porque ali você está próximo aos grandes dramas sociais, aos grandes dramas familiares e se coloca muito próximo, numa educação olho no olho. É aquela história: a tecnologia de ponta ainda é o ser humano. É isso aí o perigo que eu falo hoje, o de querer transformar a EJA em educação a distância. A gente está precisando de olho no olho.

Entrevistadores: Nesse ponto, você está tocando na política pública, não é mesmo? É possível pensar política pública para a juventude sem encaixar a questão da EJA? E, mais ainda, nessas políticas públicas propostas para a juventude, aonde ainda deixamos a desejar? Você consegue pensar algumas questões? 
Eliane Ribeiro: Eu acho que a gente tem, relacionando com a juventude, um grande pepino que é o ensino médio porque parece que agora a reforma do ensino médio foi uma coisa da cabeça do governo. Claro que não é, já vinha sendo discutida a questão do ensino médio há 15, 20 anos, por quê? Porque o ensino médio tem um problema de identidade - qual é o papel do ensino médio? O que é efetivamente? 0 que se agrega? Então, se ele ficar só vinculado com o vestibular, empobrece; se ele ficar vinculado ao mundo do trabalho e tal, também empobrece. Eu acho que não é uma questão só para o professor. Eu colaboro dando aulas numa universidade lá no Uruguai, num mestrado de juventudes, e o grande barato, a grande discussão deles hoje é essa. Na Argentina, a mesma coisa. Acho que é uma questão de muitos países.

Entrevistadores: Não é só nossa, né?!

Eliane Ribeiro: Não é só nossa, e todos vêm discutindo qual é o papel do ensino médio; pelo menos é a proposta que querem colocar. Então, não dá para pensar política pública descolada, haja visto todos os ganhos e conquistas que a gente teve nos últimos 15 anos, sem sobras, com os indígenas, a EJA, serviço social, os quilombolas.

\section{Entrevistadores: A SECADI.}

Eliane Ribeiro: É, a SECADI, com embates importantes, campos de disputas importantes. Agora, efetivamente, a EJA ainda é sim um "penduricalho" na educação. A EJA não é tratada na justa medida, dentro do sistema, junto com o ensino fundamental e com o ensino médio.

Entrevistadores: Você está falando também sobre juventude, aproximando desse contexto da EJA, mas também tensionando com a questão do ensino médio, dessa necessidade de reentendimento do ensino médio, um redimensionamento. $\mathrm{Na}$ verdade, falar em juventudes e das demandas das juventudes é uma coisa relativamente recente, inclusive como campo de pesquisa, né? Se analisarmos bem outros campos, vemos que eram mais consolidados. Como é que você interpreta isso, se eu tenho por outro lado, aqueles sujeitos que vão lidar com a juventude e que, muitas vezes, não têm a formação para isso também, gerações e gerações, que são os professores. Como é que isso impacta, nessa nova forma de estar com as juventudes, que têm essa pluralidade, tem esse cenário e nós professores inclusive?

Eliane Ribeiro: Eu acho que a própria categoria juventude é uma categoria nova. $\mathrm{A}$ escola ajudou a criar a juventude, né?! Como é que era antigamente? Você saía basicamente da infância e já casava muito jovem, meninas com treze, catorze anos. A escola ajudou muito nesse sentido. Alguns pensadores vão falar muito sobre isso, como é que a escola vai ajudando a construindo a juventude, nessa noção de juventude. Então, hoje no Brasil é considerada, para as políticas públicas, na categoria juventude, quem vai de quinze a vinte e nove anos. Há países que já vão até trinta nove anos...

Entrevistadores: Vai crescendo a expectativa de vida. 
Eliane Ribeiro: Cresce a expectativa de vida, crescem as dificuldades de se achar no mercado de trabalho. Então você vai empurrando a juventude, cada vez ele (mercado) vai ficando também jovem.

Entrevistadores: Está mais elástico.

Eliane Ribeiro: Mais elástico. É como você falou, é uma categoria super jovem, até de estudo, como a gente pensa sobre ela. Os grandes estudiosos vão começar na década de sessenta, como Bourdieu, que tem um texto clássico, que é "A Juventude apenas uma palavra". No qual ele vai mostrar que a juventude é sempre um campo de disputa: quando é conveniente, eu jogo ela para infância, quando eu não quero... - isso acontece muito dentro de casa, não é?!(risos). A mãe diz: "está muito jovem pra sair!"; ou então: "está muito velha, tem que arrumar um emprego". Isso é uma pressão muito forte. Então, aqui no Brasil, a gente vai ter efetivamente, a partir do final dos anos 1990, os estudos. Tem o estudo clássico da Helena Abramo, com os punks em São Paulo. Têm todas essas novas identidades e tal, que é bem o que interessa ao trabalho da Helena. Mas sempre a juventude esteve muito atrelada à questão da escola; ser jovem era ser estudante. E eu acho que o grande barato, hoje em dia, é você pensar a juventude - ela não é só estudante, ela é um monte de outras coisas. Então, vemos a juventude trabalhadora, a juventude produtora de cultura, a juventude promovendo a sociabilidade - família, mãe, pai -, então assim tem um monte de dimensões. Não dá para pensar a juventude só naquele "quadradinho". Por isso que eu acho que o nosso campo de educação é um campo muito interdisciplinar. Às vezes, as pessoas não entendem, porque às vezes as pessoas olham a escola só! Como se a escola existisse por ela, mas a escola está num contexto, entendeu?! Não dá para a gente olhar para a escola sem olhar a geografia, sem olhar as artes, sem olhar as ciências sociais...

Entrevistadores: A questão da saúde.

Eliane Ribeiro: Da saúde. Olha, tem um negócio super interessante. Em 2005, a gente fez uma pesquisa que era sobre a juventude sulamericana. Eram seis países da América do Sul, fizemos com o IBASE, um monte de gente. $\mathrm{E}$, naquele momento, aparece a maior demanda da juventude e que não estava na nossa pesquisa, isso a gente não tinha colocado como...

Entrevistadores: Como categoria.

Eliane Ribeiro: Como estudo, como categoria, foi a questão da mobilidade; do transporte. Acontece que isso explodiu no passe livre, nessas coisas todas e, agora, eu fui em uma reunião faz duas semanas em São Paulo, sobre uma pesquisa que foi feita no Brasil. E o que aparece é que eles também não estavam procurando isso e o que surge? A questão da saúde mental que é muito interessante, tipo uma espécie de adoecer em torno dessa questão de falta de alternativa, de desemprego, de dizer: para onde que eu vou?

Entrevistadores: Se pensar bem... 
Eliane Ribeiro: É como a Regina Novaes fala: "a juventude é o espelho retrovisor da sociedade".

Entrevistadores: E trabalhando as questões de uma forma muito descentralizadas porque eles estão partindo muitas vezes de outros pontos de vista.

Eliane Ribeiro: Exatamente. E tem a questão fundamental que é a questão da experiência, que para eles é fundante, para quem está começando a vida, então muitas vezes as experiências, "ah não faça isso!". Mas tem que fazer, eu fiz e tal. É como você falou que acontece, eu acho que nesse mundo, que é um mundo de muita transição, transição de valores, de desejos, de se colocar no mundo, de assumir identidade, eu acho que aí você toca em uma questão importantíssima que é a questão de os professores muitas vezes não estarem preparados. É como a situação da tecnologia: você está numa sala de aula falando um monte de coisa e o aluno sai dali e vai para internet, né?!

Entrevistadores: Não sai mais, faz lá na hora. Nem sai dali.

Eliane Ribeiro: Começa uma pessoa na internet falando melhor que você, muito mais interessante, às vezes. Isso coloca em questão uma série de coisas para os professores. Acho que tem uma crise, sim, do nosso papel: o que é ser professor hoje? Como é que a gente se coloca como mediador frente a esse conhecimento?

Entrevistadores: Que tipo de formação é importante?

Eliane Ribeiro: Que tipo de formação, né?! E eu acho que quem está colocando a gente na parede é a juventude. Qual é o nosso papel hoje? Olha, eu estudei, eu entrei para a faculdade em 1978 no IFCS, que era uma faculdade interessante na UFRJ, eu fui fazer Ciências Sociais. Eu lembro que era assim... professor entrava falava e saía, e ninguém abria a boca - isso num curso de Sociologia.

Entrevistadores: Linha dura, ditadura ainda.

Eliane Ribeiro: Por mais que você fosse do movimento estudantil e tal, primeiro que você não tinha essa discussão das identidades, de ser mulher, de ser negro, de ser homossexual, de ser isso... não estava, nem existia.

Entrevistadores: Não estava entre os cânones (risos).

Eliane Ribeiro: Não, não estava. Então, assim, eu fico pensando como é que a gente na escola, na escola pública, vive com essa diversidade, com o aluno nesse padrãozinho que tem o que falar, o que dizer.

Na pesquisa de doutorado do Professor Lincoln, já resgatando um pouco o início do papo, os estudantes do ensino médio de escolas estaduais foram questionados sobre como eles construíam sentidos da relação da escola com a comunidade - que foi o aspecto central da pesquisa. E o centro das respostas foi a partir da escola.

Entrevistadores: $E$ é interessantíssimo reconhecer os sentidos diferentes que os estudantes atribuíam a isto que apareceu como uma palavra dominante: escola. E isso tudo que você está colocando, de alguma forma, estava refletido ali, porque outra palavra que surgiu nas evocações deles foi professor. 
DOI: $10.12957 / \mathrm{e}-m o s a i c o s .2018 .36937$

Eliane Ribeiro: Tem um papel relevante, né?

Entrevistadores: Sentidos variados que eles davam à figura do professor.

Entrevistadores: Posso imaginar.

Entrevistadores: É incrível como você e como eles têm essa dimensão crítica, mas também de referência, tanto de um lado como do outro.

Eliane Ribeiro: Eu acho que os estudiosos mostram que professor é uma referência ou para o bem ou para o mal (risos), mas é uma referência, né? Por exemplo, se fala assim: o que você gostava na sua escola? Eles geralmente lembram de um professor, né?

Entrevistadores: Lembram de algum.

Eliane Ribeiro: A universidade de hoje, com toda a dinâmica muito interessante, ainda tem as formaturas como uma grande homenagem aos professores, né? Os alunos se preocupam com os professores que vão chamar; onde eles vão ser colocados na mesa; como serão convocados. Eu acho que os professores são redes, podem ser redes superimportantes pra essa garotada.

Entrevistadores: Interessantíssimo.

Eliane Ribeiro: Eu vejo, por exemplo, aqui os meninos que vem para a graduação, são muito pobres. Mas que vão à luta e correm atrás e, de repente, você fala assim: por que você não faz um mestrado? Aí o aluno diz: "Pô, mestrado?"

Entrevistadores: Pra eles, é outro mundo.

Eliane Ribeiro: Nessa história, então você já tá vendo, você não estava falando das pesquisas insurgentes? Um monte de gente que vem da escola pública, da periferia, das comunidades e que hoje estão como professores universitários.

Entrevistadores: Que emergiram muitos dessa juventude.

Eliane Ribeiro: Dessa juventude exatamente, já temos algumas gerações. A gente já tem geração que tá vindo dessa história. Algumas pessoas não valorizam muito isso. Eu valorizo e eu relaciono com as políticas públicas.

Entrevistadores: Claro, claro.

Eliane Ribeiro: Acho que as políticas públicas têm um papel fundamental. Eu acho que tem um papel fundamental para você estimular e fomentar isso. Se não a pessoa não consegue ficar. Se não tiver bolsa, bolsa de assistência, então. Para passagem, pra ir pra escola, pra faculdade ou pra onde for. Mas se tiver acesso para ir a um... eu tenho uma aluna aqui que falou um negócio muito legal, ela falou pra mim: professora já entendi tudo, já estou correndo atrás do capital cultural (risos). Eu falei: exatamente.

Entrevistadores: Sistemática, né?

Eliane Ribeiro: É, é sim. E eu acho muito legal! Mas isso tudo valorizando também a sua cultura e as suas formas de criação. Ah! é muito legal ir ao Centro Cultural 
DOI: $10.12957 / \mathrm{e}-m o s a i c o s .2018 .36937$

Banco do Brasil, todo mundo tem que ter acesso a isso. Mas também é muito legal ir ao que se produz, né?

Entrevistadores: Claro.

Eliane Ribeiro: Nas periferias, nas comunidades e tal.

Entrevistadores: É que a afirmação não pode se dar só de um lado.

Eliane Ribeiro: Exatamente.

Entrevistadores: A condição da política afirmativa, ela também afirma os valores do outro. Não é só dar acesso.

Eliane Ribeiro: Exatamente. Aquela coisa bem freiriana. Então eu acho que é olhar isso. Agora eu acho que para o professor é um desafio, sinceramente. Eu acho que a gente ainda tem aí anos para se refazer como professor diante disso tudo. Dessas novas gerações aí de professores. Talvez já vão chegar com outras experiências. Eu acho que a esperança tá em vocês porque, sinceramente gente, eu acho que é difícil.

Entrevistadores: Reconhecer a juventude e as suas demandas é algo relativamente recente em nosso país. Como você interpreta o papel de professores e das práticas docentes neste cenário?

Eliane Ribeiro: A gente entra numa escola e vê cada história... Eu conto sempre uma história, que, pra mim, foi uma das mais chocantes. No Pro-Jovem, quando a gente estava fazendo a avaliação, a gente correu em todas as escolas do Pro-Jovem e, de repente, eu cheguei numa escola e tinha uma professora, tinha uma moça assim quase dormindo na porta sentada aí eu falei assim: Ah, aqui tá tendo classe do Pro-Jovem? Ah... tem sim, ela respondeu. Eu falei: os meninos estão lá com algum professor? Não, eles estão lá sem fazer nada, respondeu a moça. Aí eu falei: por quê? Ela falou: Era minha aula. Eu falei: A sua aula é de que? Ela falou: de inglês. Eu falei assim: e você não tá dando aula? Ela falou: Não, eles não precisam de inglês. Ou seja, o que passa na cabeça dessa professora, por meio desse olhar para outro como cidadão de segunda categoria, né? Ou seja, inglês não é para todos ou é pra alguns? Então, a gente precisa, para fazer educação, a gente precisa querer que o outro aprenda, né?

\section{Entrevistadores: Sim.}

Eliane Ribeiro: O mínimo que você tem é querer acreditar no outro, querer que o outro aprenda. Todo dia é ganhar, seduzir. Você tem que ser um pouco artista também pra isso, né? É sim gente, eu acho que tem. Você tem é que puxar da garotada, porque o conhecimento é um negócio fantástico, bárbaro. Mas que nem outro dia eu vi um negócio no Facebook que eu adorei numa escola: conhecimento não é pra humilhar, é pra enriquecer as pessoas.

Entrevistadores: Sim, é.

Eliane Ribeiro: Exatamente, se você usa o conhecimento pra humilhar os outros, vá embora, tchau. Agora, quando você utiliza esse conhecimento pra despertar curiosidade, o interesse, o menino vai, a menina vai pra escola. 
Entrevistadores: Por aí, então, é que passa sua motivação, pros seus projetos?

Eliane Ribeiro: Pois é, eu agora estou estudando, estou fechando uma pesquisa chamada "Jovens Nem-Nem".

Entrevistadores: Nós ficamos bem curiosos sobre sua pesquisa.

Eliane Ribeiro: É porque eu tenho, eu sempre tive muita má vontade com esse termo "nem-nem", nem estuda, nem trabalha. Porque eu acho que é um termo que, no Brasil, especialmente, ele traz estigma, entendeu? Porque a juventude já é tratada de uma forma estigmatizada, né? O que o jovem é? Ah, é violento, é drogado, é consumista, é isso, é aquilo e aquilo outro.

Entrevistadores: As negatividades.

Eliane Ribeiro: 0 que que é negativo. Então eu falo assim: gente, "nem-nem" é uma coisa que é muito estigma e sempre ouvi assim: os jovens "nem-nem" são $23 \%$ da população ou $33 \%$ da população. Nós vamos desagregar os dados e trabalhar com dois bancos de dados: da PNAD e do IBGE. São voltados para a nossa pesquisa de Juventude Brasil que a gente, com esse livro que a gente fez junto com a Secretaria Nacional da Juventude no Governo Dilma ${ }^{7}$. Que foi uma pesquisa nacional com 3.000 jovens em cima de uma amostra estatística. Os dados representativos dos bancos de dados da PNAD, separamos os chamados "nem-nem". Quando nós separamos, perguntamos: quem são esses jovens?

Entrevistadores: Quem são esses jovens que não estudam e não trabalham? Por que eles como foco da pesquisa?

Eliane Ribeiro: Mulheres, a grande maioria de mulheres, assim uns $70 \%$ são mulheres. Aí você vai ver... a grande maioria com filho. Como assim?

Entrevistadores: Mulheres que chegaram a cursar o ensino médio ou saíram no ensino fundamental?

Eliane Ribeiro: Não, não. Muitos que ficaram no meio do caminho.

Eliane Ribeiro: É, mas também você vai percebendo que o "nem-nem" não é uma situação estática, tá? "Nem-nem" é o seguinte: hoje eu sou "nem-nem", mas amanhã eu não sou, tá? Então, por exemplo...

Entrevistadores: $O$ filho cresce, bota numa creche.

Eliane Ribeiro: Exatamente, lembrei muito dos nossos alunos da Educação de Jovens e Adultos que estudam hoje, amanhã não estão estudando porque conseguiram um bico, foram cuidar da vida. Mas no dia seguinte retornam. Então é isso, então falei: bom, de "nem-nem" eles não têm nada, estão "sem-sem", né? Estão sem trabalho e sem...

Entrevistadores: E provisoriamente.

\footnotetext{
7 PINHEIRO, Diógenes; RIBEIRO, Eliane; VENTURI, Gustavo; NOVAES, Regina (orgs.). Agenda
} juventude Brasil: leituras sobre uma década de mudanças. Rio de Janeiro: Unirio, 2016. 
Eliane Ribeiro: É, provisoriamente. Eu acho que a gente tem se debruçado nisso pra tentar traçar o perfil, efetivamente, de quem são esses jovens.

Entrevistadores: Como assim, os jovens podem ser agrupados de décadas em décadas para ser possível traçar um perfil, os "nem-nem"? Mas como vocês conseguem agrupá-los?

Eliane Ribeiro: A nossa pesquisa é realizada a partir da pesquisa Agenda Juventude Brasil, de 2014, realizada com a Secretaria Nacional de Juventude. Usamos a PNAD de 2016 para dialogar com os dados da pesquisa Agenda Juventude Brasil. Nesse debate o IBGE começa a não tratar mais esses jovens como "nem-nem", mas utiliza a expressão não estudam e não estão ocupados, já que detectam o trabalho doméstico como central na vida desses sujeitos.

Entrevistadores: Sim, sim.

Eliane Ribeiro: Isso é muito legal gente, a universidade pode ter um papel.

Entrevistadores: Claro.

Eliane Ribeiro: É bom porque o IBGE hoje está tratando os jovens como não ocupados naquele momento da pesquisa e que não estavam no mercado de trabalho, por exemplo.

Entrevistadores: Sim.

Eliane Ribeiro: Porque esse termo "nem-nem" é criado na Inglaterra numa outra situação, numa conjuntura de jovens com alta escolaridade. Jovens que ficaram desempregados com a crise da Europa.

Entrevistadores: Não tem nada a ver conosco.

Eliane Ribeiro: Muito diferente da gente, né? Então, o que a gente está tentando ver é o perfil desses jovens. Estamos tentando analisar o perfil, por exemplo, uma jovem que não está estudando e que não está trabalhando, mas ela está com um bebê - é compreensível isso.

Entrevistadores: Sim.

Eliane Ribeiro: E, às vezes, vale mais a pena você ficar em casa, cuidando do seu filho do que trabalhar.

Entrevistadores: Esta é uma ocupação de mãe.

Eliane Ribeiro: E é uma mega...

Entrevistadores: E até o conceito de ocupação muda um pouco.

Eliane Ribeiro: Tem sim. Eu vou mandar pra vocês um artigo nosso que saiu agora e que tem um dado da PNAD que aí eu acho que eu nunca entrei na discussão de gênero, mas a gente vai ter que entrar porque é uma discussão.

Entrevistadores: Tem uma clivagem importante. 
Eliane Ribeiro: Tem total. Nesse artigo, a gente mostra, por exemplo, uma coisa impressionante: jovens que não estão estudando e nem trabalhando. Mas que são responsáveis por tarefas domésticas. Tem jovens homens representados por um fino fio amarelo e, as jovens mulheres, é um negócio desse tamanho (grande), um negócio muito impressionante. A gente entende como é o país da gente. $\mathrm{E}$ como a questão do gênero é determinante. Então, a gente tem que tentar é olhar esses perfis que, muitas vezes, aparecem no levantamento das manchetes de jornais sobre os "nem-nem" - uma coisa horrível, entendeu? Parece que é um bando de vagabundos. Delinquentes, violentos.

Entrevistadores: Culpabilizados.

Eliane Ribeiro: Culpabilizados. A gente pode mexer um pouco com esse grupo hoje de jovens que chega num momento em que eles estão trabalhando com a cultura. $\mathrm{E}$ muitas vezes você pergunta pra eles: você trabalha? Não, não estou trabalhando. Não reconhecem seu próprio trabalho porque é temporário, por exemplo.

Entrevistadores: Sim.

Eliane Ribeiro: Eu digo pra eles: não, você trabalha.

Entrevistadores: Como é bico, como é esporádico; eles não reconhecem aquilo.

Eliane Ribeiro: Exatamente, ele é um DJ, ele é um...

Entrevistadores: Tá tirando o valor da ocupação dele de um outro lugar que não é.

Eliane Ribeiro: Exatamente. E aí você tem que saber perguntar. É isso que eu acho que o IBGE agora está trabalhando e que eu achei muito legal. Estão fazendo um estudo, umas agregações super interessantes, bem bacanas. Então, assim, eu acho que o próprio IBGE foi percebendo que tem esse perfil.

Entrevistadores: Quais são os contextos de fato?

Eliane Ribeiro: Eu venho retrabalhando isso aí porque se você trabalha com isso, como uma verdade, que existem jovens que não fazem absolutamente nada, você vai construir políticas públicas nessa perspectiva e essas políticas não vão dar certo, porque não é bem assim a vida deles. Isso a gente tem um exemplo concreto, que foi o Pro-Jovem. Primeiro ano de Pro-Jovem era para os jovens que não estudavam e não trabalhavam. O que aconteceu? Tiveram que mudar o programa porque perceberam que os que não estudavam hoje, estudavam amanhã; não trabalhavam hoje, mas trabalhavam amanhã. Não é uma situação de opção: Ah, eu vou agora ficar sem estudar e sem trabalhar e é isso que eu quero da minha vida.

Entrevistadores: Não é mesmo.

Eliane Ribeiro: Não é assim que a banda toca né, gente?! Então, estamos trabalhando nessa perspectiva também de transição escola-trabalho também com o pessoal do Uruguai que tem estudos muito bacanas sobre essa área.

Entrevistadores: Incrível que você pensou numa situação aqui de inatividade, que eu achei interessante, mas que, na verdade, não existe. A pessoa está trabalhando 
muitas vezes, está exercendo o papel, às vezes, como chefe de família, está organizando a família, está financiando todo mundo dentro da casa.

Eliane Ribeiro: Todo mundo na família depende dele.

Entrevistadores: E que não tem nada de inativo. Aí, você chama esse sujeito de inativo. $\mathrm{Na}$ verdade você está distorcendo um grande contexto. Está dando sustentação pra economia, inclusive.

Eliane Ribeiro: Exatamente, lá no dia da apresentação do IBGE, que esse pessoal apresentou um monte de trabalho, tinha um que era exatamente sobre isso que vocês estão falando. Mostrando como é olhar pra uma sociedade que vai depender da aposentadoria. Porque segura, né? A aposentadoria acaba segurando as novas gerações, muitas vezes você dá uma possibilidade de um neto teu estudar.

Entrevistadores: Sim.

Eliane Ribeiro: Vovô, vovó, segura a onda. Como vai ser com essa reforma trabalhista que pega as aposentadorias e racha? Isso vai impactar.

Entrevistadores: E cada vez mais porque a população está envelhecendo, é uma característica.

Eliane Ribeiro: Envelhecendo muito.

Entrevistadores: E vivendo mais (risos). Tem mais demandas.

Eliane Ribeiro: Exatamente. E é também muito interessante se você olhar os idosos. Hoje, eles estão cheios de demandas.

Entrevistadores: E essa massa de jovens vai ter que sustentar essa; esse grupo. E essa situação não passa a atingir só o pai que perdeu o emprego...

Eliane Ribeiro: Exatamente.

Entrevistadores: Mas a relação aluno-escola...

Eliane Ribeiro: E aí isso abala as estruturas da família, da nossa sociedade patriarcal. E muitas famílias estão sendo sustentadas pelas mulheres, muitas famílias estão sendo sustentadas pelos jovens. A gente acha pouco, mas, por exemplo, eu vejo aqui um aluno nosso, que tem uma bolsa de mestrado de mil e quinhentos reais, isso tem um impacto familiar assim incrível, incrível. Vários alunos meus falam assim: professora agora, lá em casa, eu é que banco o gás, a luz, eu não sei mais o que.

Entrevistadores: É incrível isso, porque muda a própria família ou aqueles que são mais próximos de um outro contexto da importância da educação porque ele tá conseguindo isso através da educação - esse financiamento é da educação.

Eliane Ribeiro: Educa também.

Entrevistadores: Abre um universo de compreensão do potencial. 
DOI: $10.12957 /$ e-mosaicos.2018.36937

Eliane Ribeiro: Na maioria das vezes, a família diz: "vai ganhar pra trabalhar fazendo o quê? Ficar fazendo nada?

Entrevistadores: Pesquisando, estudando, indo pra campo, viajando, calma aí....

Eliane Ribeiro: O que é isso pra família?

Entrevistadores: Exatamente, é algo que, como você apontou, isso chegou num determinado, numa determinada camada da população, que antes nem pensava nisso.

Eliane Ribeiro: Gente, mas não tinha "nem-nem"

Entrevistadores: De exceções.

Eliane Ribeiro: Não tinha mesmo. Outro dia eu estava vendo a foto da minha formatura e a foto da formatura do meu filho, agora, três anos atrás no IFCS. Parece que é um outro mundo. Mundo que eu frequentei e agora o mundo que ele frequentou.

Entrevistadores: E você continua na universidade, continua próximo da juventude.

Eliane Ribeiro: Ainda bem, né, gente.

Entrevistadores: Então sobre essa coisa do consumo que a Chris trabalha muito, na verdade, esse consumo hoje está muito variado, não é mesmo? Desse grupo da juventude.

Entrevistadores: Tá muito diverso. Ao mesmo tempo que agrupa, desagrupa, de certa forma.

Eliane Ribeiro: Da imagem, né?

Entrevistadores: Você prefere continuar vivendo perto dos jovens?

Eliane Ribeiro: Eu não tenho condição de aposentar ainda não, eu vou perturbar ainda. Eu amo meus alunos. Ontem de noite estavam todos na ANPEdinha e começaram a mandar fotos. É o que eu quero daqui pra frente? Quero continuar a pesquisar, o que eu gosto muito. E gosto de dar aula também. E ficar com essa garotada que traz muita coisa pra gente.

Entrevistadores: Porque dá energia.

Eliane Ribeiro: Ah, que dá muita energia, ensina muita coisa pra gente.

Entrevistadores: Faz você pensar a todo tempo.

Entrevistadores Eu diria até uma valorização da arte que, na verdade, os jovens têm se apropriado muito disso.

Entrevistadores: É a informação; a universalização.

Eliane Ribeiro: E é muito bacana. Outro dia eu estava dentro da sala de aula com os alunos de periferia. E como que eles entram e como que eles vão se reconhecendo, construindo identidade. $\mathrm{E}$ daqui um cadinho, já construindo 
DOI: $10.12957 /$ e-mosaicos.2018.36937

identidade, ele fala alguma coisa de arte, não sei o quê e fala assim: professora você não conhece o Basquiat? (risos)

Eliane Ribeiro: Gente, de onde vocês conhecem Basquiat? Ah, porque Basquiat... e me deram uma aula de Basquiat.

Entrevistadores: Mas é porque eles estão mais próximos do Basquiat do que a gente. (risos)

Eliane Ribeiro: Exatamente, a questão da identidade e eles viram que eu fui me interessando e tal e trouxeram um monte de gente, superbacana.

Entrevistadores: E é esse tipo de consumo que dá identidade (e coesão) a essa juventude.

Eliane Ribeiro: Exatamente, e trouxeram na outra aula - aqui eu dou muita aula para licenciatura. Que eu adoro, amo. Acho que curso de Pedagogia sozinho não tá com nada e bota o povo junto e gente... Aí misturam o garoto de Teatro, da Música, da Biologia, da Matemática.

Entrevistadores: Pra eles é ótimo e pra gente também.

Eliane Ribeiro: É muito legal isso.

Eliane Ribeiro: E sabe o que eu acho legal? É que essa galera faz perguntas pra gente sobre educação de uma maneira que a gente não pensa.

Entrevistadores: Um outro olhar.

Eliane Ribeiro: De repente o garoto faz uma pergunta que você fica... porque a gente está dentro de uma narrativa muito já consolidada e tal. E ele vem com uma questão de fora e pá! E bota pra você e você... Ahm? Tá bom, como que é que eu vou responder isso, né? Então, eu adoro dar aula para licenciatura e dou todo semestre. Por isso eu conheço todo mundo aqui e tem gente muito legal. Dar aula pro pessoal de Teatro é muito bom.

Entrevistadores: Eu estou na licenciatura de Artes Visuais (Profa Christiane Arcuri) e é bem bacana. E eles trabalham, fazem estágio em todos esses museus, centro culturais e têm um outro olhar. Eles sempre questionam o ensino em sala de aula e o ensino regular, no caso, quando eles vão fazer estágio no CAp. O que é bem diferente de quando eles têm a conversa com o público que vai até o museu.

Entrevistadores: Muita obrigada e obrigado.

Eliane Ribeiro: Nada, nada. Adorei, voltem sempre. 